\title{
Biostimulants Enhanced Seedling Root Growth and Bulb Yields of True Seed Shallots (Allium
}

\section{cepa var aggregatum L.)}

\author{
Agung, I.G.A.M.S.; Diara, I.W.
}

Study Program of Agroecotechnology, Faculty of Agriculture, Udayana University, Bali, Indonesia

\begin{abstract}
The objective of this research was to investigate the effects of biostimulan (PGPR) on root growth of seedlings and bulb yields of true seeds shallots (TSS). The research was conducted in the glasshouse in Tangtu village, Badung regency,Bali province of Indonesia, from April until October 2018. Complete randomized block design was used with 4 replications. Three kinds of biostimulants $(B, C, D)$ and one control, and two TSS varieties (Sunren F1 and Tuktuk) were the treatments imposed. Results of experiment showed that biostimulants as well as TSS variety significantly $(P<0.05)$ increased germination percentage, root length of TSS seedlings, leaf chlorophyll content, bulb diameter, bulb number, leaf and bulb fresh weight per pot. However there was no significant different effect between types of biostimulant. Interaction effect between biostimulants and TSS variety was only significant on leaf chlorophyll content. Biostimulant application could be expected to increase growth and yields of TSS.
\end{abstract}

Keywords-Biostimulants, bulbs, roots, true seed shallots.

\section{INTRODUCTION}

The use of true shallot seeds (TSS) is increasing particularly in Indonesia due to its advantages compared to seed bulbs (Basuki, 2009). The benefits of TSS are free from pathogen, small amounts of planting materials, easier transporting and storaging, producing healthier crops and bigger bulbs (Ridwan et al., 1998; Permadi, 1993; Sumaratne et al., 2005. The use of TSS ia economically beneficial due to doubling the yields compared to seed bulb crops van den Brink and Basuki, 2011). However, the slow growth of seedlings in the nursery takes 21-25 days to be able to transplant into the field resulted in longer time in producing bulbs compared to seed bulb crops. Seed priming has been proved to increase seed germination and reduce abnormal seedlings of onions ((Allium cepa cv. aggregatum L.) (Caseiro et al., 2004; Sevarani and Umarani, 2011; Jagosz, 2015). Biostimulant or plant growth promoting rhizobacteria (PGPR), is a group of beneficial bacteria actively colonizing the rhizosphere and important in increasing plant growth (Rahni, 2012). Research results showed that bacteria of Pseudomonas, Azotobacter, Bacillius dan Serratia genus were identified as phytohormone producers such as auxin, cytokinin, gibberellin, ethylene and absisic acids that were able to enhance the growth and yield of plants (Rahni, 2012). GA3 significantly enhanced seed germination, index of seedling vigour and the speed of seedling emergence of true seed shallots variety Tuktuk compared to KNO3 (Agung and Diara, 2017). Steptomyces griseoviridis was also reported to produce auksin and IAA invitro which is able to stimulate plant growth (Fitrah-pratiwi et al., 2017). Biostimulants that contain Pseudomonas fluorescens colonize the rooting zones of bamboo were reported to increase the solubility of soil phosphorus. Some strains of Pseudomonas fluorescens can avoid the infection of soil pathogen fungi and is used as biocontrol agents commercially in the glasshouse and in the fields (Arshad and Frankenberger, 1997).

\section{METHODOLOGY}

The research was conducted in the glasshouse in Tangtu village, Badung regency,Bali province of Indonesia, from April until October 2018. The objective of this research was to investigate the effects of biostimulan (PGPR) on root growth of seedlings and bulb yields of true seeds shallots (TSS). Complete randomized block design was used with 4 replications. Three kinds of biostimulants (B, C, D) and one control, and two TSS varieties (Sunren F1 and Tuktuk) were the treatments imposed. Biostimulant B consisted of Rhizobia, Azospirillum sp., Bacillus subtilis, Aspergilus niger, Lactobacillus sp, Pseudomonas putida. Biostimulant C consisted of total bacteria, Azosprillum sp., Azotobacter sp. and $\mathrm{N}$ fixed bacteria. Microorganisms in biostimulant D were Pseudomonans fluorescence, Trichoderma, Aspergillus niger, Azotobacter, Azospirilum and Rhizobium. After soaking in each biostsimulant for 24 hours, 25 seeds were germinated in petridshes as well as on moistened tissues wrapped with transparent plastic sheets. Seedlings were 
then transplanted into $20 \mathrm{~cm}$ diam pots. Germination percentage of seeds, root length of seedlings, leaf chlorophyll content, bulb diameter, bulb number, leaf and bulb fresh weight per pot were the variable measured.

\section{RESULTS AND DISCUSSION}

\subsection{Germination Percentage}

Biostimulants as well as variety significantly $(\mathrm{P}<0.05)$ increased the germination percentage of TSS. Biostimulants resulted in $41.37 \%$ higher germination than control (Table 1). There was no difference effect between types of biostimulants. Sunren F1 variety had $41.67 \%$ higher germination than Tuktuk variety (Table 1). There was no effects of interaction between types of biostimulant and TSS variety on germination percentage.

\subsection{Seedling Root lengths}

Seedling root lengths of both varieties were significantly $(\mathrm{P}<0.05)$ increased by biostimulants. Biostimulants resulted in $27.65 \%$ higher root longer rooth lengths compared to control (Table 1). Variety of Sunren F1 produced $64.44 \%$ longer roots than Tuktuk (Table 1). There was no effects of interaction between Biostimulant and TSS variety on seedling root lengths. Rhizobacteria promote better root development directly through production of phytohormones and indirectly by inhibiting pathogen infection with synthesis of different substances (Benizri et al., 2001).

\subsection{Leaf Chlorophyll Content}

There was significant $(\mathrm{P}<0.05)$ effect of interaction between types of biostimulant and variety on leaf chlorophyll content. Biostimulants significantly increased leaf chlorophyll both on variety of Sunren F1 and Tuktuk although the effects on Sunren F1 higher than on Tuktuk. Leaf chlorophylls were increased by $58 \%, 48 \%$ and $60 \%$ due to biostimulants $\mathrm{A}, \mathrm{B}$ and $\mathrm{C}$ application respectively compared to without biostimulant (Table 2). The total chlorophyll content was also reported to be significantly stimulated by $P$. agglomeranset Proteamaculansen on tomato leaves (Moustaine et al., 2017) in comparison with other treatments.

\subsection{Leaf and Bulb Fresh Weights and Bulb Number per Pot}

Biostimulant significantly increased $(\mathrm{P}<0.05)$ leaf and bulb fresh weights (FW) and bulb number per pot (Table 1). These parameters were $38.05 \%, 48.09 \%$ and $38,43 \%$ respectively higher than control. The effects of biostimulant were not different among types of biostimulant. Variety of Sunren F1 produced significantly higher values of those variables than
Tuktuk (Table 1). Better root growth caused by the effects of biostimulant enhanced the absorbtion of soil nutrients and moisture surrounding roots and finally increased plant growth. As it well known biostimulant is defined as formula that contains living microorganisms which have potential to colonize plant roots and enhance plant growth due to increasing the availability and the acquisition of soil nutrients (Packialakshmi and Aliya, 2014). Biostimulant or Plant growth promoting rhizobacteria (PGPR) is basic components of biofertilzer. Strains of PGPR such as Burkkholderia, Azospirillium, Enterobacter, Azotobacter, Erwinia, Rhizobium and Flavobacterium have proved that function (Rodriguez and Fraga, 1999). The biostimulants increased the availability of soil nutrients (N, P, Zn and Fe) as well as production of phytohormones which were categorized as phytosimulators) (Naveed et al., 2008). Representatives of Bacillus and Pseudomonas were reported as bioinoculants with high potential on cereals (Talic et al., 2006).Better plant growth, due to biostimulant application resulted in increased leaf number and leaf fresh weights. Enhancement of leaf growth and other shoot parts contributed to increasing photosynthates and finally enhancing the growth of shallot bulbs compared to without biostimulants. Variety of Sunren F1 may be genetically better than Tuktuk so its growth and yield performance were higher (Table 1).

\subsection{Bulb Diameter}

Biostimulants significantly $(\mathrm{P}<0.05)$ increased diameter of shallot bulbs. Bulb diameter was $27.92 \%$ bigger due to biostimulant application compared to without biostimulant. Sunren F1 variety had $64.83 \%$ bigger bulb diameter compared to Tuktuk (Table 1). Cell division, cell elongation, cell formation, and the formation of new tissue required carbohydrates. Carbohydrate synthesis was heavily influenced by the ability of plants to perform photosynthesis (Husen, 2007), although Sumiyati et al. (2016) did not find any differences in bulb diameter of shallots due to PGPR application.

\section{CONCLUSION}

Biostimulants significantly $\quad(\mathrm{P}<0.05) \quad$ increased germination percentage, root length, leaf and bulb fresh weights and bulb number of TSS per pot. Biostimulants increased root length, bulb fresh weights, bulb number, leaf chlorophyll content and bulb diameter. by $27.65 \%$, $45.09 \%, 38.43 \%, 55.33 \%$ and $27.92 \%$ respectively. There was no different effect between types of biostimulant. Variety Sunren F1 performed higher values than Tuktuk in all parameters. There was significant interaction effect between types of biostimulant and variety only on leaf chlorophyll content. 


\section{ACKNOWLEDGEMENTS}

Authors greatly appreciated the Department of Research Technology and Higher Education of Republic of Indonesia and Udayana University for granting the research funds. The assistance of Dr. Khamdan Kalimi in preparing samples for microbe identifications and SAM analysys of seedling roots was also appreciated.

\section{REFERENCES}

[1] Agung, IGAMS and Diara, I.W. 2017. Pre-sowing treatment enhanced germination and vigour of true shallot (Allium cepa var. aggregatum) seeds. International of Environment, Agriculture and Biotechnology (IJEAB).2 (6): 3262-3267.

[2] Arshad. M. and Frankenberger, W.T. 1997. Plant Growth-Regulating Substances in the Rhizosphere: Microbial Production and Functions. Advances in Agronomy 62:45-151.

[3] Basuki, R.S. 2009. Analisis kelayakan teknis dan ekonomis teknologi budidaya bawang merah dengan biji botani dan benih umbi tradisional. Jurnal Hortikultura vol.19.no.2: 214-227.

[4] Benizri, E., Baudoin, E. and Guckert, A. 2001. Root colonization. Biocontrol Science and Technology, 11 (5): $557-574$

[5] Caseiro, R., Bennett, M.A. and Marcos-Filho, J. 2004. Comparis on of three priming techniques for onion seed lots differing in initial seed quality. Seed Science and Technology 32: 365-375.

[6] Fitrah-Pratiwi, Marlina dan Mariana. 2017. Pengaruh pemberian plant growth promoting rhizobacteria (pgpr) dan akar mabu terhadap pertumbuhan dan hasil bawang merah (Allium ascalonicum L.). Agrotropika Hayati, 4(2): 77-83

[7] Husen, E., Wahyudi A.T., Suwanto, A., Giyanto. 2011. Growth enhancement and disease reduction of soybean by 1-aminoacyclopropane-1-carboxylate deaminase-producing Pseudomonas. American Journal of Applied Sciences, 8: 1073-1080

[8] Jagosz, B. 2015. Improving onion seed germination using priming treatments. Infrastructure and Ecology of Rural Areas IV (4): 147-1447.

[9] Moustaine M., Elkahkahi R., Benbouazza A., Benkirane R., Achbani E.H. 2017. Effect of plant growth promoting rhizobacterial (PGPR) inoculation on growth in tomato (Solanum Lycopersicum L.) and characterization for direct PGP abilities in Morocco. International Journal of Environment, Agriculture and Biotechnology (IJEAB). Vol-2, Issue-2.: p.590..

[10] Naveed, M., Zahir, Z.A., Khalid, M., Asghar, H.N. and Akhtar, M.J. and Arshad, M. 2008.
Rhizobacteria containing ACC-deaminase for improving growth and yield of wheat under fertilized conditions. Pakistan Journal of Botany, 40 (3): 1231-1241

[11] Packialakshmi, $\mathrm{N}$ and R.T. Aliya. 2014. Comparative study of vermicast and charcoal used as carrier inoculums to the biofertilizer preparation. Bio. Med. Res., 1(1): 1-6.

[12] Permadi, A.H. 1993. Growing shallot from true seed. Research results and problems. Onion Newsletter for the Tropics. NRI. No. 5: 35-38.

[13] Rahni, N.M. 2012. Efek fitohormon terhadap pertumbuahn tanaman jagung (Zea mays). Artikel Dosen Agroteknologi Universitas Haluoleo.(In Bahasa Indonesia).

[14] Ridwan, H., Sutapraja, H. dan Margono. 1998. Daya produksi dan harga pokok benih bawang merah. Buletin penelitian Hortikultura, vol.XVII no.4: 5761.

[15] Rodriguez, H. and Fraga, R. 1999. Phosphate solubilizing bacteria and their role in plant growth promotion. Biotechnology Advance, 17 (4-5): 319339.

[16] Sumiyati, T., Sulistyaningsih, E., Wibowo, A. 2016. Effects of plant growth promoting rhizobacteria (PGPR) on growth and yield of shallot in sandy coastal land. Ilmu Pertanian (Agricultural Science), 1 (3): 105:110.

[17] Selvarani, K. and Umarani, R. 2011. Evaluation of seed priming methods to improve seed vigour of onion (Allium cepa cvaggregatum) and carrot (Daucus carota). Journal of Agricultural Technology 7(3): 857-867.

[19] Sumanaratne, J.P., Palipane, W.M.u. dan Sujeewa Kumary, L.G. 2005. Feasibility of small onion (Allium cepa L. Aggregatum Group) cultivated from true seed. Annals of the Sri Langka Department of Agriculture no.4: 39-46.

[20] Talic, N.F., Evans, C., and Zaki, A.M. 2006. Inhibition of orthodontically induced root resorption with echistatin, an RGD-containing peptide. American Journal of Orthod. Dentofacial Orthop., 129: $252-260$.

[21] van den Brink, L. and Basuki, R.S. 2011. Production of true seed shallots in Indonesia. ISHS Acta Horticulturae 958: I International Symposium on Sustainable Vegetable Production in Southeast Asia.DOI:10.1.7660/Acta.Hortic.2012.958.12.Sustai nable Vegetable Production in Southeast Asia. DOI:10.1.7660/Acta.Hortic.2012.958.12. 
Table 1. Effects of biostimulants and variety on percentage of seed germination, root length of seedlings,

leaf $F W$ pot $^{-1}$, bulb number pot ${ }^{-1}$, bulb diameter, and bulb FW pot ${ }^{-1}$.

\begin{tabular}{|c|c|c|c|c|c|c|}
\hline Treatments & $\begin{array}{c}\text { Percentage of } \\
\text { seed } \\
\text { germination } \\
(\%) \\
\end{array}$ & $\begin{array}{l}\text { Root length } \\
\text { of seedlings } \\
\text { (cm) }\end{array}$ & $\begin{array}{l}\text { Leaf FW } \\
\left(\mathrm{g} \mathrm{pot}^{-1}\right)\end{array}$ & $\begin{array}{c}\text { Bulb } \\
\text { number } \\
\text { (bulbs pot } \\
\text { 1) } \\
\end{array}$ & $\begin{array}{c}\text { Bulb } \\
\text { diameter } \\
(\mathrm{mm})\end{array}$ & $\begin{array}{l}\text { Bulb FW } \\
\left(\text { g pot }^{-1}\right)\end{array}$ \\
\hline \multicolumn{7}{|l|}{ Biostimulan } \\
\hline $\mathrm{A}(\mathrm{Control})$ & $42,67^{\mathrm{b}}$ & $4,07^{\mathrm{b}}$ & $14.0^{\mathrm{b}}$ & $2.3^{\mathrm{b}}$ & $16.11^{\mathrm{b}}$ & $16.6^{\mathrm{b}}$ \\
\hline$B$ & $71,00^{\mathrm{a}}$ & $6,05^{\mathrm{a}}$ & $21.5^{\mathrm{a}}$ & $4.0^{\mathrm{a}}$ & $24.41^{\mathrm{a}}$ & $31.6^{\mathrm{a}}$ \\
\hline C & $73,33^{\mathrm{a}}$ & $5,38^{\mathrm{a}}$ & $21.5^{\mathrm{a}}$ & $3.7^{\mathrm{a}}$ & $20.74^{\mathrm{a}}$ & $28.2^{\mathrm{a}}$ \\
\hline$D$ & $74,00^{\mathrm{a}}$ & $5,45^{\mathrm{a}}$ & $24.8^{\mathrm{a}}$ & $3.5^{\mathrm{ab}}$ & $21.91^{\mathrm{a}}$ & $30.9^{\mathrm{a}}$ \\
\hline LSD $5 \%$ & 14,931 & 0,844 & 7.170 & 1.208 & 4.477 & 8.850 \\
\hline \multicolumn{7}{|l|}{ Variety } \\
\hline Sunren F1 & $76,50^{\mathrm{a}}$ & $7,79^{\mathrm{a}}$ & $27.85^{\mathrm{a}}$ & $5.0^{\mathrm{a}}$ & $30.76 \mathrm{a}$ & $40.6^{\mathrm{a}}$ \\
\hline Tuktuk & $54,00^{\mathrm{b}}$ & $2,77^{\mathrm{b}}$ & $13.05^{\mathrm{b}}$ & $1.7^{\mathrm{b}}$ & $10.82 b$ & $13.0^{\mathrm{b}}$ \\
\hline LSD $5 \%$ & 10,558 & 0.597 & 5.070 & 0.854 & 3.165 & 6.258 \\
\hline
\end{tabular}

Notes: Figures followed by the same letters in the same colomn and treatment are not significantly different at $5 \%$ LSD.

Table 2. Interaction Eefects of Biostimulants and Variety on LeafChlorophyll Content.(SPAD)

\begin{tabular}{l|c|c|c|c}
\hline \multicolumn{4}{c}{ Treatments } & \multicolumn{4}{c}{ Biostimulants } \\
\hline Variety & A (control) & B & C & D \\
\hline Sunren F1 & $22.2 \mathrm{~g}$ & $52.3 \mathrm{~b}$ & $43.1 \mathrm{~d}$ & $56.0 \mathrm{a}$ \\
Tuktuk & $23.1 \mathrm{fg}$ & $27.2 \mathrm{f}$ & $34.7 \mathrm{e}$ & $47.6 \mathrm{c}$ \\
\hline
\end{tabular}

Notes: Figures followed by the same letter (s) are not significantly different at 5\% Duncan Multiple Range Test. 